\title{
OPTIMASI FORMULASI PEMBUATAN MI BASAH DENGAN CAMPURAN PASTA UBI UNGU (Ipomea batatas L.,) DENGAN PROGRAM LINIER
}

\author{
Sumartini \\ Thomas Ghozali \\ Latyhifah Hasya Layalia \\ Program Studi Teknologi Pangan, Fakultas Teknik, Universitas Pasundan, Jl. Dr.Setiabudi No 93, Bandung, \\ 40153, Indonesia \\ E-mail : $\underline{\text { tinitafsil@yahoo.com }}$
}

\begin{abstract}
Abstrak
Tujuan penelitian adalah untuk menentukan formulasi bahan baku pembuatan mi ubi ungu yang optimal dengan menggunakan program linier, sehingga dapat diperoleh produk mi basah yang sesuai dengan standar SNI. Manfaat penelitian ini memberikan informasi kepada masyarakat tentang pemanfaatan ubi ungu sebagai campuran tepung terigu dan penambahan bahan tambahan pangan yang aman digunakan dalam pembuatan mi sehingga diperoleh produk mi basah yang sehat dan aman dikonsumsi.Penelitian ini menggunakan program linier, dengan kadar protein dan kadar air sebagai faktor pembatas. Faktor pembatas tersebut diperoleh dari acuan Standar Nasional Indonesia yang sudah ditetapkan pada tahun 1992. Program linier dapat menghasilkan suatu formulasi yang optimal dengan bermutu baik dan harga terjangkau. Hasil penelitian pendahuluan, analisis kimia pasta ubi ungu mengandung kadar air 58.79\%, kadar protein 1.1\% dan total anthosianin $20.64 \mathrm{mg} / \mathrm{l}$. Carboxy Methyl Celulose mengandung kadar air 4.43\%, Sodium Try Poly Phosphate 1\%, dan natrium bikarbonat mengandung kadar air sebesar $1.95 \%$. hasil uji hedonik penelitian pendahuluan volume 500ml terpilih sebagai jumlah penambahan air pada proses pembuatan larutan garam. Mi basah campuran pasta ubi ungu formula III adalah formula terpilih dengan harga sebesar Rp. 1530.13/200gram berdasarkan program linier. Formulasi III mengandung kadar protein 12,20\%, kadar air 52.09\% dan total antosianin $16.90 \mathrm{mg} / \mathrm{l}$.
\end{abstract}

\section{Pendahuluan}

Konsumen dewasa ini memiliki kesadaran akan penyediaan pangan yang sehat semakin besar. Konsumen semakin kritis menuntut tersedianya pangan yang enak, murah, memiliki komposisi gizi yang baik, aman dikonsumsi. Makanan tersebut mengandung zat-zat atau komponen yang dapat berfungsi menjaga atau meningkatkan kesehatan (berfungsi sebagai makanan fungsional. Salah satu jenis makanan yang cukup populer dan memiliki tingkat penerimaan yang tinggi dalam masyarakat adalah mi. Komposisi bahan pembuat mi juga dapat di modifikasi sehingga memungkinkan digunakannya berbagai bahan yang memiliki keunggulan tertentu untuk dapat meningkatkan kualitasnya (Purnawijayanti, 2009).

Umumnya bahan dasar pembuatan mi adalah tepung terigu. Tepung terigu merupakan produk import sehingga perlu dilakukan alternatif lain untuk bahan baku mi. Salah satu usahanya adalah memperkenalkan potensi alam Indonesia yang melimpah namun belum dimanfatkan secara maksimal seerti halnya ubi jalar.

Ubi jalar memiliki kelebihan disamping nilai gzinya yaitu sebagai pewarna alami. Zat pewarna alami yang berpotensi untuk diekstrak adalah antosianin dari ubi jalar ungu.
Kandungan antosianin pada ubi jalar ungu lebih tinggi daripada ubi yang berwarna putih, kuning dan jingga. Di antara ubi jalar ungu, kultivar Ayamurasaki dan Murasakimasari merupakan sumber pigmen antosianin dengan produksi dan kestabilan warna yang tinggi (Suardi, 2005).

Teknik optimasi yang akan digunakan pada penelitian ini adalah program linier. Program linier merupakan salah satu teknik analisis dari kelompok teknik riset operasional yang menggunakan model matematika. Tujuannya adalah untuk mencari, memilih dan menentukan alternatif yang terbaik dari sekian alternatif layak tersedia. (Supranto, 1983).

Tujuan dilakukan penelitian ini adalah untuk menentukan formulasi bahan baku pembuatan mi ubi ungu yang optimal dengan menggunakan program linier, sehingga dapat diperoleh produk mi basah yang sesuai dengan Standar Nasional Indonesia.

Manfaat dari penelitian yang dilakukan adalah Memberikan informasi kepada masyarakat tentang pemanfaatan ubi ungu sebagai campuran tepung terigu dan penambahan bahan tambahan pangan yang aman digunakan dalam pembuatan mi 
sehingga diperoleh produk mi basah yang sehat dan aman dikonsumsi.

\section{Bahan dan Metode}

Bahan baku utama yang digunakan dalam penelitian ini adalah tepung terigu cakra kembar protein tinggi, ubi ungu umur 3-3.5 bulan, air, garam, Sodium tripolyphosphate $\mathrm{Na}_{5} \mathrm{P}_{3} \mathrm{O}_{10}(S T P P)$, Carboxyl Methyl Celulose (CMC), dan Natrium Bikarbonat $\left(\mathrm{NaHCO}_{3}\right)$.

Bahan-bahan yang digunakan untuk analisis kimia adalah mi ubi ungu, toluen, larutan $\mathrm{Na}_{2} \mathrm{SO}_{4}$ anhidrat, larutan $\mathrm{HgO}$, selenium black, batu didih, $\mathrm{H}_{2} \mathrm{SO}_{4}$ pekat, aquadest, larutan $\mathrm{NaOH} 30 \%$, larutan $\mathrm{Na}_{2} \mathrm{~S}_{2} \mathrm{O}_{3} 5 \%$, dan granul seng.

Alat-alat yang digunakan dalam penelitian ini adalah gelas ukur, dandang (panci kukusan), cobek, timbangan digital, baskom plastik, pencetak/pemotong mi,(roll press), dan panci perebusan.

Alat-alat yang digunakan untuk analisis kimia adalah gelas kimia, labu didih, alat destilasi lengkap dengan kondensor.

\section{Metode Penelitian}

Penelitian Pendahuluan

Pemilihan Penambahan Air Pada Pembuatan Larutan Garam Alkali

Mi basah yang dibuat pada penelitian pendahuluan dibuat melalui 3 macam penambahan air. Pembuatan larutan garam dimulai dengan mencampurkan bahan kering seperti : $C M C, S T P P$, garam dan natrium bikarbonat, kemudian ditambahkan air hingga 500ml, 750ml dan $1000 \mathrm{ml}$.

Pembedaan ketiga penambahan air tersebut dimaksudkan untuk memperoleh kualitas mi yang dihasilkan. Pengujian ini dilakukan terhadap 15 panelis dengan 3 kali ulangan untuk menentukan satu formulasi air yang terbaik berdasarkan penilaian panelis terhadap atribut mutu warna mi, aroma mi, tekstur mi, dan kenampakan mi. Contoh kriteria penilaian untuk uji mutu hedonik yang digunakan untuk atribut mutu kenampakan mi adalah sebagai berikut :

Tabel 1. Kriteria Penilaian Uji Mutu Hedonik

\begin{tabular}{|l|c|}
\hline \multicolumn{1}{|c|}{ Skala } & Skala numerik \\
\hline Sangat Suka & 6 \\
Suka & 5 \\
Agak Suka & 4 \\
Agak Tidak Suka & 3 \\
Tidak Suka & 2 \\
Sangat Tidak Suka & 1 \\
\hline
\end{tabular}

Analisis Bahan Baku

Bahan-bahan pembuatan mi basah dilakukan analisis yaitu pasta ubi ungu dilakukan analisis kadar protein dan kadar air, sedangkan bahan baku lainnya seperti Carboxyl Methyl Celulose, Sodium trypolyphosphate dan natrium bikarbonat dilakukan analisis kadar air. Komposisi bahan baku ini kemudian dijadikan sebagai variabel perubah keputusan (variabel tetap) dalam pemodelan program linier sehingga diperoleh formulasi mi basah yang optimal berdasarkan perhitungan program linier.

Penelitian Utama Feasible Berdasarkan Perhitungan Program Linier.

Penelitian utama yang dilakukan ialah penentuan optimalisasi formula pembuatan mi basah dari pasta ubi ungu menggunakan program linier. Formula mi basah ubi ungu yang digunakan adalah formula yang feasible berdasarkan program linier. Jika formulasi yang dihasilkan tidak feasible maka akan digunakan formulasi lain hingga diperoleh produk mi ubi ungu dengan formulasi yang feasible. Diagram alir proses pembuatan mi basah ubi ungu dapat dilihat pada Gambar 3.

Tahap optimalisasi formula mi basah ubi ungu dengan program linier adalah sebagai berikut

1. Menentukan Fungsi Tujuan Mi basah ubi ungu

Fungsi tujuan yang dipergunakan bersifat minimasi, yaitu minimasi biaya yang dikeluarkan untuk pembuatan mi basah campuran pasta ubi ungu. Persamaan linier fungsi tujuannya adalah sebagai berikut:

$$
\begin{gathered}
\mathrm{Z}_{1}=\mathrm{C}_{1} \mathrm{X}_{1}+\mathrm{C}_{2} \mathrm{X}_{2}+\mathrm{C}_{3} \mathrm{X}_{3}+\mathrm{C}_{4} \mathrm{X}_{4}+\mathrm{C}_{5} \mathrm{X}_{5}+\mathrm{C}_{6} \mathrm{X}_{6} \\
+\mathrm{C}_{7} \mathrm{X}_{7}
\end{gathered}
$$

Keterangan :

$\mathrm{Z}_{\mathrm{n}}$ : Fungsi tujuan (minimasi biaya) pembuatan mi basah.

$\mathrm{Cn}$ : Harga per satuan unit jenis bahan baku/gram yang digunakan

$\mathrm{Xn}$ : Jenis bahan baku ke-n yang digunakan dalam pembuatan mi basah.

2. Menentukan model variabel antara komponen kimia bahan baku dan jenis bahan baku yang akan dicari formulasi optimal, yaitu:

a. Variabel keputusan (variabel berubah) : Tepung Terigu $\left(\mathrm{X}_{1}\right)$, Pasta Ubi Ungu $\left(\mathrm{X}_{2}\right)$, Carboxyl Methyl Celulose $\left(\mathrm{X}_{3}\right)$, Sodium Tri Poly Phospate $\left(\mathrm{X}_{4}\right)$, Garam $\left(\mathrm{X}_{5}\right)$, Natrium Bikarbonat $\left(\mathrm{X}_{6}\right)$ dan Air $\left(\mathrm{X}_{7}\right)$.

b. Variabel perubah keputusan (variabel tetap) : Protein $\left(a_{1}\right)$ dan Air $\left(a_{2}\right)$

Pemodelan dari program linier dalam pembuatan mi basah ubi ungu dapat dilihat pada Tabel 2. 
Tabel 2. Model Variabel Komposisi Kimia Bahan Baku Sosis Vegetarian Formula Ke-n

\begin{tabular}{|l|c|c|c|}
\hline \multicolumn{1}{|c|}{ Bahan Baku $\left(\mathrm{X}_{\mathrm{n}}\right)$} & \multicolumn{2}{c|}{$\begin{array}{c}\text { Kandungan Kimia }\left(\mathrm{a}_{\mathrm{n}}\right)(\%) \\
\left(\mathrm{C}_{\mathrm{n}}\right)(\mathrm{Rp} / \mathrm{g})\end{array}$} \\
\cline { 2 - 3 } & Protein $\left(\mathrm{a}_{1}\right)$ & $\mathrm{Air}_{\left(\mathrm{a}_{2}\right)}$ & $\mathrm{c}_{1}$ \\
\hline Tepung Terigu $\left(\mathrm{X}_{1}\right)$ & $\mathrm{a}_{11}$ & $\mathrm{a}_{21}$ & $\mathrm{c}_{2}$ \\
\hline Pasta Ubi Ungu $\left(\mathrm{X}_{2}\right)$ & $\mathrm{a}_{12}$ & $\mathrm{a}_{22}$ & $\mathrm{c}_{3}$ \\
\hline Carboxyl Methyl Celulose $\left(\mathrm{X}_{3}\right)$ & $\mathrm{a}_{13}$ & $\mathrm{a}_{23}$ & $\mathrm{c}_{4}$ \\
\hline Sodium Tri Polu Phospate $\left(\mathrm{X}_{4}\right)$ & $\mathrm{a}_{14}$ & $\mathrm{a}_{24}$ & $\mathrm{c}_{5}$ \\
\hline Garam $\left(\mathrm{X}_{5}\right)$ & $\mathrm{a}_{15}$ & $\mathrm{a}_{25}$ & $\mathrm{c}_{6}$ \\
\hline Natrium Bikarbonat $\left(\mathrm{X}_{6}\right)$ & $\mathrm{a}_{16}$ & $\mathrm{a}_{26}$ & $\mathrm{c}_{7}$ \\
\hline Air $\left(\mathrm{X}_{7}\right)$ & $\mathrm{a}_{17}$ & $\mathrm{a}_{27}$ & \\
\hline
\end{tabular}

3. Menentukan Fungsi Pembatas

Fungsi pembatas diambil berdasarkan interaksi antara jenis bahan baku $\left(\mathrm{X}_{1} \cdot \mathrm{X}_{2} \cdot \mathrm{X}_{3} \mathrm{X}_{4} \cdot \mathrm{X}_{5} \cdot \mathrm{X}_{6} \mathrm{X}_{7}\right)$ dengan komponen kimia bahan baku (a1 ... a2) yang terbatas, yaitu aiXn yang bersifat minimum atau maksimum. Fungsi pembatas terbagi menjadi dua jenis yaitu :

1. Fungsi pembatas yang membatasi persentase kandungan gizi yang terkandung dalam produk akhir. Nilai kandungan gizi yang ingin dicapai, ditentukan berdasarkan kandungan gizi produk seperti yang terlihat pada Tabel 7 .

Tabel 3. Pembatas Kandungan Kimia Produk Akhir Mi Basah

\begin{tabular}{|l|l|c|}
\hline Kandungan Kimia & Persyaratan & satuan \\
\hline Protein $\left(\mathrm{b}_{1}\right)$ & Min8 & $\%$ \\
\hline Air $\left(\mathrm{b}_{2}\right)$ & Mak 35 & $\%$ \\
\hline
\end{tabular}

(Sumber : Badan Standar Nasional Indonesia)

2. Fungsi pembatas yang membatasi persentase penggunaan bahan baku yang digunakan. Penggunaan bahan baku ditentukan berdasarkan jumlah minimal atau maksimal penggunaan hingga diperoleh formulasi mi basah ubi ungu yang feasible.

a. Fungsi pembatas komponen kimia

1. Fungsi pembatas Protein minimal $8 \%\left(b_{1}\right)$ : $a_{11} X_{1}+a_{12} X_{2} \geq b_{1}\left(X 1 \cdot X_{2} \cdot X_{3} \cdot X 4 \cdot X_{5} \cdot X_{6} X_{7}\right)\left(a_{11}-\right.$ $\left.b_{1}\right) X_{1}+\left(a_{12}-b_{1}\right) X_{2} \geq 0$

2. Fungsi pembatas Air maksimal $35 \%\left(b_{2}\right)$ : $a_{21} X_{1}+a_{22} X_{2}+a_{23} X_{3}+a_{24} X_{4}+a_{25} X_{5}+a_{26} X_{6}+a_{27} X_{7}$ $\leq \mathrm{b}_{2}\left(\mathrm{X} 1 \cdot \mathrm{X}_{2} \cdot \mathrm{X}_{3} \mathrm{X} 4 \cdot \mathrm{X}_{5} \cdot \mathrm{X}_{6} \mathrm{X}_{7}\right)\left(\mathrm{a}_{21}-\mathrm{b}_{2}\right) \mathrm{X}_{1}+\left(\mathrm{a}_{22}-\right.$ $\left.\mathrm{b}_{2}\right) \mathrm{X}_{2}+\left(\mathrm{a}_{23}-\mathrm{b}_{2}\right) \mathrm{X}_{3}+\left(\mathrm{a}_{24}-\mathrm{b}_{2}\right) \mathrm{X}_{4}+\left(\mathrm{a}_{25}-\mathrm{b}_{2}\right) \mathrm{X}_{5}+$ $\left(a_{26}-b_{2}\right) X_{6}+\left(a_{27}-b_{2}\right) X_{7} \leq 0$

b. Fungsi pembatas bakan baku

1. Fungsi pembatas bahan baku keseluruhan: $\mathrm{X}_{1}+\mathrm{X}_{2}+\mathrm{X}_{3}+\mathrm{X}_{4}+\mathrm{X}_{5}+\mathrm{X}_{6}+\mathrm{X}_{7}=\mathrm{Q}_{\mathrm{T}}$

2. Fungsi pembatas Tepung Terigu $\left(\mathrm{X}_{1}\right): \mathrm{X}_{1}=\mathrm{Q}_{1}$ $x Q_{T}$

3. Fungsi pembatas Pasta Ubi Ungu $\left(\mathrm{X}_{2}\right): \mathrm{X}_{2}=$ $\mathrm{Q}_{2} \times \mathrm{Q}_{\mathrm{T}}$

4. Fungsi pembatas CMC $\left(\mathrm{X}_{3}\right): \mathrm{X}_{3} \geq \mathrm{Q}_{3} \times \mathrm{Q}_{\mathrm{T}}$

5. Fungsi pembatas $\operatorname{STPP}\left(\mathrm{X}_{4}\right): \mathrm{X}_{4} \geq \mathrm{Q}_{4} \times \mathrm{Q}_{\mathrm{T}}$

6. Fungsi pembatas Garam $\left(\mathrm{X}_{5}\right): \mathrm{X}_{5}=\mathrm{Q}_{5} \times \mathrm{Q}_{\mathrm{T}}$

7. Fungsi pembatas Natrium Bikarbonat $\left(\mathrm{X}_{6}\right): \mathrm{X}_{6}$ $=\mathrm{Q}_{6} \times \mathrm{Q}_{\mathrm{T}}$

8. $\quad$ Fungsi pembatas Air $\left(\mathrm{X}_{7}\right): \mathrm{X}_{7}=\mathrm{Q}_{7} \times \mathrm{Q}_{\mathrm{T}}$

Analisis Produk Mi Basah Ubi Ungu
Sampel mi basah feasible selanjutnya dilakukan analisis kimia dengan parameter uji meliputi kadar protein metode Kjedahl (AOAC, 2005), kadar air metode Oven (AOAC 2005).

Uji Organoleptik Mi Basah

Pengujian organoleptik dengan uji hedonik terhadap ketiga formulasi mi basah dari pasta ubi ungu feasible berdasarkan pemrograman linier. Pengujian ini dilakukan terhadap 15 panelis untuk menentukan satu formulasi mi basah ubi ungu terbaik berdasarkan penilaian panelis terhadap atribut mutu warna, aroma, rasa, dan tekstur mi. Contoh kriteria penilaian untuk uji mutu hedonik yang digunakan untuk atribut kenampakan mi adalah sebagai berikut :

Tabel 4. Kriteria Penilaian Uji Hedonik Penelitian Utama

\begin{tabular}{|l|c|}
\hline \multicolumn{1}{|c|}{ Skala } & Skala numerik \\
\hline Sangat Suka & 6 \\
Suka & 5 \\
Agak Suka & 4 \\
Agak Tidak Suka & 3 \\
Tidak Suka & 2 \\
Sangat Tidak Suka & 1 \\
\hline
\end{tabular}

\section{Penentuan Produk Terpilih}

Produk terpilih berdasarkan pemrograman linier, uji organoleptik dan analisis kimia kemudian dibandingkan untuk mengetahui apakah hasil dari ketiga uji tersebut memiliki persamaan atau tidak. Apabila masing-masing hasil uji berbeda, maka produk terbaik ditentukan berdasarkan komposisi kimia yang mendekati dengan komposisi kimia mi basah berdasarkan SNI 01-2987-1992.

Analisis Produk Terpilih

Analisis ini dilakukan terhadap sampel terpilih Mi Basah kemudian dilakukan analisis kadar total antosianin metode $\mathrm{pH}$ differensial (AOAC, 2005).

\section{Hasil dan Pembahasan}

Penelitian Pendahuluan

Pembuatan Pasta Ubi Ungu

Pengolahan pasta ubi jalar diperoleh dari penghancuran ubi jalar yang telah dikukus selama \pm 20 menit dengan suhu $\pm 100^{\circ} \mathrm{C}$ kemudian dilakukan trimming kulit dan dilakukan penghancuran hingga halus. Keuntungan dari 
penggunaan pasta ubi jalar ungu adalah waktu produksi yang lebih singkat dibandingkan dengan pembuatan tepung ubi jalar. Warna yang didapatkan dari pasta ubi ungu lebih baik dibandingkan dengan tepung ubi jalar ungu. Kelemahan penggunaan dibanding dengan tepung yaitu pasta tidak memiliki umur simpan yang lama, hal ini dikarenakan tingginya kadar air yang terkandung dalam pasta ubi jalar (Affy, 2010).

Ubi ungu jika akan dijadikan pasta terlebih dahulu mengalami proses pengukusan dimana pengukusan berfungsi untuk menonaktifkan enzim fenolase yang terdapat di dalam umbi sehingga reaksi pencoklatan selama pembuatan pasta umbi dapat dicegah. Adanya panas yang diberikan pada ubi selama proses pengukusan mengakibatkan enzim yang ada dalam ubi mengalami kematian. Hal ini dikarenakan protein enzim, baik apoenzim dan eksoenzim mengalami denaturasi. Keadaan ini mengakibatkan enzim-enzim yang ada pada ubi ungu menjadi mati. Selain inaktifasi enzim, prinsip proses pengukusan juga akan menurunkan aktifitas bahkan mematikan mikroorganisme dan juga dapat mengakibatkan tekstur bahan menjadi lebih lunak.

Tabel 5. Analisis Kimia Penelitian Pendahuluan

\begin{tabular}{|l|c|c|c|}
\hline \multirow{2}{*}{$\begin{array}{c}\text { Jenis } \\
\text { Bahan }\end{array}$} & \multicolumn{3}{|c|}{ Analisis } \\
\cline { 2 - 4 } & Pro & Air & Anto \\
\hline Pasta Ubi & $1.1 \%$ & $58.79 \%$ & $20.64 \mathrm{mg} / \mathrm{l}$ \\
\hline CMC & - & $4.43 \%$ & - \\
\hline STPP & - & $1.0 \%$ & - \\
\hline $\mathrm{NaHCO}_{3}$ & - & $1.95 \%$ & - \\
\hline
\end{tabular}

Tabel 5, menunjukkan bahwa ubi jalar merupakan jenis tanaman pertanian yang memiliki kandungan protein rendah sebesar $1.1 \%$, sedangkan hasil analisis kadar protein ubi jalar berbagai varietas seperti kidal, ayamurasaki, sari dan jago menurut (Affy, 2010) dengan metode pasta berkisar antara 1.58-2.35\%. Steinbaeur dan Kushman (1971), mengatakan bahwa ubi jalar merupakan bahan pangan dengan gizi yang cukup tinggi karena merupakan sumber energi dalam bentuk gula dan karbohidrat. Selain itu ubi jalar juga mengandung berbagai vitamin dan mineral yang dibutuhkan oleh tubuh.

Ubi jalar tidak mempunyai komponen gluten yaitu suatu massa yang kohesif dan viskositas yang dapat meregang secara elastis. Gluten merupakan komponen terpenting dalam tepung terigu yang berupa protein glutenin dan gliadin yang telah beraksi dengan air sehingga membentuk massa yang elastis dan ekstensibel.

Kadar protein yang rendah akan berdampak pada saat proses pembuatan mi, dimana kadar protein yang diharuskan dalam proses pembuatan mi ini adalah minimal $8 \%$. Dalam pembuatan mi, protein sangat berpengaruh karena dalam pembuatan mi dibutuhkan protein yaitu gluten. Maka dari itu pada pembuatan mi basah, pasta ubi ungu berfungsi sebagai bahan pensubstitusi, sedangkan bahan baku utama yaitu tepung terigu sehingga pada proses pembuatan mi kadar protein yang diinginkan akan tercapai.

Ubi jalar ungu merupakan salah satu tanaman umbi yang mengandung antosianin, yang dapat terlihat dari warna ungu yang ditampakkan oleh umbinya. Peningkatan nilai guna ubi jalar ungu salah satunya caranya ialah pembuatan pasta sebagai bahan pensubstitusi pembuatan mi basah. Tujuan penggunaan pasta ubi ungu dalam pembuatan mi basah salah satunya ialah meningkatkan nilai gizi dan antioksidan serta memberikan warna ungu yang menarik pada mi basah yang dihasilkan.

Penentuan Penambahan Air pada Pembuatan Larutan Garam Alkali

Penentuan jumlah penambahan air yang tepat pada pembuatan larutan garam alkali yang akan digunakan pada pembuatan mi basah. Komposisi bahan baku pembuatan larutan garam alkali terdapat pada Tabel 6.

Tabel 6. Komposisi Bahan Baku Pembuatan Larutan Garam Alkali Penelitian Pendahuluan

\begin{tabular}{|c|c|c|c|c|c|c|}
\hline \multirow[t]{2}{*}{ Komponen Bahan Penyusun Mi Basah } & \multicolumn{2}{|c|}{ F I } & \multicolumn{2}{|c|}{ F II } & \multicolumn{2}{|c|}{ F III } \\
\hline & $\%$ & $\mathrm{~g}$ & $\%$ & $\mathrm{~g}$ & $\%$ & $\mathrm{~g}$ \\
\hline Carboxyl Methyl Celulose & 1.4 & 7 & 0.9 & 7 & 0.7 & 7 \\
\hline Sodium Try Poly Phosphate $\left(\mathrm{Na}_{5} \mathrm{P}_{3} \mathrm{O}_{10}\right)$ & 0.3 & 1.5 & 0.2 & 1.5 & 0.15 & 1.5 \\
\hline Garam Dapur $(\mathrm{NaCl})$ & 8 & 40 & 5.3 & 40 & 4 & 40 \\
\hline Natrium Bikarbonat $\left(\mathrm{NaHCO}_{3}\right)$ & 0.3 & 1.5 & 0.2 & 1.5 & 0.15 & 1.5 \\
\hline Air & 90 & 450 & 93.4 & 700 & 95 & 950 \\
\hline
\end{tabular}

diperoleh ditambahkan dalam pembuatan adonan pada ke 
Tabel 7. Komposisi Pembuatan Mi Ubi Ungu Penelitian Pendahuluan

\begin{tabular}{|l|c|c|c|c|c|c|}
\hline \multirow{2}{*}{$\begin{array}{c}\text { Komponen Bahan Penyusun } \\
\text { Mi Basah }\end{array}$} & \multicolumn{2}{|c|}{ F I } & \multicolumn{2}{c|}{ F II } & \multicolumn{2}{c|}{ F III } \\
\cline { 2 - 7 } & $\%$ & g & $\%$ & g & $\%$ & g \\
\hline Tepung Terigu & 56.25 & 225 & 56.25 & 225 & 56.25 & 225 \\
\hline Pasta Ubi Ungu & 31.25 & 125 & 31.25 & 125 & 31.25 & 125 \\
\hline $\begin{array}{l}\text { Konsentrasi Larutan Garam } \\
\text { Alkali }\end{array}$ & 12.5 & 50 & 12.5 & 50 & 12.5 & 50 \\
\hline
\end{tabular}

Formulasi mi basah yang dibuat dari ketiga formula pada Tabel 7, kemudian dilakukan uji organoleptik. Respon organoleptik yang di uji terhadap mi basah yang dihasilkan dari ketiga formulasi di atas adalah warna, aroma,

\section{Uji Organoleptik Penelitian Pendahuluan}

Tabel 8. Hasil Organoleptik Penentuan Penambahan Volume Air Pada Pembuatan Larutan Garam Alkali

\begin{tabular}{|l|c|c|c|c|c|c|}
\hline \multirow{2}{*}{$\begin{array}{c}\text { Komponen Bahan Penyusun } \\
\text { Mi Basah }\end{array}$} & \multicolumn{2}{|c|}{ F I } & \multicolumn{2}{c|}{ F II } & \multicolumn{2}{c|}{ F III } \\
\cline { 2 - 7 } & $\mathbf{\%}$ & $\mathbf{g}$ & $\mathbf{\%}$ & $\mathbf{g}$ & $\mathbf{\%}$ & $\mathbf{g}$ \\
\hline Tepung Terigu & 56.25 & 225 & 56.25 & 225 & 56.25 & 225 \\
\hline Pasta Ubi Ungu & 31.25 & 125 & 31.25 & 125 & 31.25 & 125 \\
\hline $\begin{array}{l}\text { Konsentrasi Larutan Garam } \\
\text { Alkali }\end{array}$ & 12.5 & 50 & 12.5 & 50 & 12.5 & 50 \\
\hline
\end{tabular}

Keterangan : Setiap huruf yang berbeda menyatakan berbeda nyata pada taraf $5 \%$.

a. Warna

Data pada Tabel 12, memperlihatkan pembuatan adonan mi basah dengan menambahkan larutan garam alkali yang dibuat dari penambahan volume air berbeda, memberikan warna mi basah yang dihasilkan tidak berbeda nyata.

Penambahan larutan garam alkali pada pembuatan mi basah ini bersifat basa yaitu berkisar antara 8-9. Hal ini disebabkan $\mathrm{pH}$ mi menjadi naik atau bersifat basa sehingga warna ungu pada mi pada untuk ketiga formulasitidak berbeda nyata. Hal ini dipengaruhi oleh senyawa yang terdapat didalam ubi ungu, ubi ungu mengandung senyawa antioksidan yaitu anthosianin. Penggunaan pasta ubi ungu pada pembuatan mi memiliki jumlah yang sama sehingga warna mi yang diperoleh tidak berbeda nyata antara perlakuan satu dengan yang lainnya.

b. Aroma

Aroma mi basah yang dihasilkan dari adonan mi yang dibuat dengan penambahan larutan garam alkali memperlihatkan hasil yang tidak berbeda nyata (Tabel 12). Aroma mi yang dihasilkan lebih banyak dipengaruhi oleh komponen yang terdapat di dalam bahan yaitu pasta ubi ungu. Timbulnya aroma pada mi disebabkan oleh zat yang bersifat volatile (menguap) yang terdapat pada ubi jalar dan terigu.

c. Tekstur

Penggunaan larutan garam alkali yang dibuat dengan penambahan air hingga $500 \mathrm{ml}$, $750 \mathrm{ml}$, dan $1000 \mathrm{ml}$ kemudian dicampurkan dalam pembuatan mi basah memberikan tekstur mi tidak berbeda nyata pada pelakuan $b_{1}$ dan $b_{2}$. Tekstur mi pada kedua perlakuan tersebut berbeda nyata kenampakan. Tujuan perlakuan ini untuk menentukan volume penambahan air yang tepat pada pembuatan mi basah dari campuran pasta ubi ungu dan terigu. dengan tekstur mi pada perlakuan $b_{3}$. Tekstur mi tidak berbeda pada pelakuan $b_{1}$ dan $b_{2}$ dikarenakan penambahan jumlah garam yang sama pada pembuatan larutan dengan jumlah air yang berbeda memberikan perbedaan larutan garam alkali yang diperoleh tidak berbeda. Hal ini mengakibatkan kemampuan garam atau ion $\mathrm{Na}^{+}$yang terdapat di dalam kedua larutan garam alkali tersebut memiliki daya ikat yang sama pada komponen-komponen yang terdapat di dalam adonan, sehingga kekentalan jaringan adonan mi sama dan memberikan tekstur mi pada kedua perlakuan tidak berbeda.

Penggunaan larutan garam alkali yang dibuat dengan menambahkan air hingga 1000ml menunjukkan tekstur mi berbeda nyata dengan kedua perlakuan terdahulu. Hal ini disebabkan semakin banyak air yang ditambahkan dalam pembuatan larutan garam alkali mengakibatkan konsentrasi $\mathrm{NaCl}$ lebih kecil, sehingga kemampuan ion $\mathrm{Na}^{+}$untuk bereaksi dengan komponen yang ada dalam adonan lebih kecil. Garam alkali yang terdiri dari Carboxyl Methyl Celulose (CMC), Sodium tripolyphosphate (STPP), Natrium Bikarbonat $\left(\mathrm{NaHCO}_{3}\right)$ dan garam yang digunakan dalam pembuatan adonan mi dapat memperkuat tekstur mi, meningkatkan fleksibilitas dan elastisitas mi dan mengikat air.

Kenampakan

Nilai kenampakan pada mi basah tidak berbeda nyata antar perlakuan. Hal ini dikarenakan warna, aroma yang dihasilkan pada produk mi basah baik, hal ini disebabkan bahan baku yaitu tepung terigu dan pasta ubi ungu dalam jumlah 
pemakaiannya sama sehingga didapatkan produk mi basah yang dapat diterima oleh panelis.

\section{Penelitian Utama}

Penentuan formulasi bahan baku dalam pembuatan mi basah ubi ungu dilakukan dengan menggunakan aplikasi program linier dengan beberapa faktor pembatas, yaitu pembatas yang membatasi kandungan nutrisi produk akhir dan pembatas yang membatasi jumlah penggunaan carboxyl methyl cellulose (CMC), Sodium Trypoly phosphate (STPP), natrium bikarbonat $\left(\mathrm{NaHCO}_{3}\right)$, garam dan air sehingga fungsi tujuan yang berupa minimasi harga dapat tercapai dengan kandungan nutrisi sesuai acuan. Pembuatan mi basah yang dilakukan dalam penelitian ini dengan menggunakan program linier dapat dilihat pada Tabel 14.

Formulasi yang dihasilkan dari program linier merupakan formula optimal dengan kandungan nutrisi memenuhi acuan pembatas yang ditetapkan dengan harga terendah. Pembatas lain yang digunakan adalah pembatas bahan baku tetap dan pembatas bahan baku berubah. pembatas bahan baku tetap ialah tepung terigu, pasta ubi ungu, garam, natrium bikarbonat $\left(\mathrm{NaHCO}_{3}\right)$ dan air, sedangkan bahan baku berubah ialah carboxyl Methyl Celulose (CMC) dan Sodium Trypoly Phosphate (STPP).

Tabel 9. Formulasi Mi Basah Dengan Program Linier

\begin{tabular}{|c|c|c|c|c|c|c|}
\hline \multirow[b]{2}{*}{ No } & \multirow[b]{2}{*}{ Bahan Baku } & \multicolumn{2}{|c|}{ Jumlah } & \multirow{2}{*}{$\begin{array}{l}\text { Harga/gram } \\
\quad(\mathrm{Rp})\end{array}$} & \multirow{2}{*}{$\begin{array}{c}\text { Harga } \\
\text { Total (Rp) }\end{array}$} & \multirow{2}{*}{$\begin{array}{l}\text { Hasil Analisis } \\
\text { Protein \& Air } \\
(\%)\end{array}$} \\
\hline & & $\%$ & Gram & & & \\
\hline \multirow{8}{*}{1} & Tepung Terigu & 56.25 & 112.5 & 9.1 & 1023.75 & \multirow{8}{*}{$\begin{array}{c}12.19 \\
\& \\
53.51\end{array}$} \\
\hline & Pasta Ubi Ungu & 31.25 & 62.5 & 7.2 & 450 & \\
\hline & Carboxyl Methyl Celulose & 0.2 & 0.4 & 100 & 40 & \\
\hline & Sodium Try Poly Phosphate & 0.025 & 0.05 & 60 & 3 & \\
\hline & Garam & 1 & 2 & 6.4 & 12.8 & \\
\hline & Natrium Bikarbonat & 0.025 & 0.05 & 55.55 & 2.78 & \\
\hline & Air & 11.25 & 22.5 & 0.08 & 1.8 & \\
\hline & \multicolumn{4}{|c|}{ Harga per 200 gram $(\mathrm{Rp})$} & 1534.13 & \\
\hline \multirow{8}{*}{2} & Tepung Terigu & 56.25 & 112.5 & 9.1 & 1023.75 & \multirow{8}{*}{$\begin{array}{c}12.12 \\
\& \\
56.81\end{array}$} \\
\hline & Pasta Ubi Ungu & 31.25 & 62.5 & 7.2 & 450 & \\
\hline & Carboxyl Methyl Celulose & 0.175 & 0.35 & 100 & 35 & \\
\hline & Sodium Try Poly Phosphate & 0.050 & 0.1 & 60 & 6 & \\
\hline & Garam & 1 & 2 & 6.4 & 12.8 & \\
\hline & Natrium Bikarbonat & 0.025 & 0.05 & 55.55 & 2.78 & \\
\hline & Air & 11.25 & 22.5 & 0.08 & 1.8 & \\
\hline & \multicolumn{4}{|c|}{ Harga per 200 gram $(\mathrm{Rp})$} & 1532.13 & \\
\hline \multirow{8}{*}{3} & Tepung Terigu & 56.25 & 112.5 & 9.1 & 1023.75 & \multirow{8}{*}{$\begin{array}{c}12.20 \\
\& \\
52.09\end{array}$} \\
\hline & Pasta Ubi Ungu & 31.25 & 62.5 & 7.2 & 450 & \\
\hline & Carboxyl Methyl Celulose & 0.15 & 0.3 & 100 & 30 & \\
\hline & Sodium Try Poly Phosphate & 0.075 & 0.15 & 60 & 9 & \\
\hline & Garam & 1 & 2 & 6.4 & 12.8 & \\
\hline & Natrium Bikarbonat & 0.025 & 0.05 & 55.55 & 2.78 & \\
\hline & Air & 11.25 & 22.5 & 0.08 & 1.8 & \\
\hline & \multicolumn{4}{|c|}{ Harga per 200 gram (Rp) } & 1530.13 & \\
\hline
\end{tabular}

Data pada Tabel 14, memperlihatkan bahwa formulasi yang dihasilkan dari program linier merupakan formula optimal yang memenuhi standar pembatas yang telah ditentukan dan harga terendah.

Pembatas kendala protein dan air masingmasing minimal $8 \%$ dan air 35\%. Data pada Tabel 9 menunjukkan bahwa formulasi III feasible dibandingkan dengan formulasi I dan II dalam pembuatan mi basah, karena biaya produksi yang dihitung dengan program linier pada formula tersebut lebih rendah dari pembuatan mi basah dengan Formula II dan I. Formulasi III dijadikan sebagai formulasi terpilih dalam pembuatan mi basah, karena biaya produksi yang diperkirakan oleh program linier pada formula tersebut memiliki harga termurah (feasible), yaitu Rp. 1530.13,/200gram mi basah yang dihasilkan.

Tabel 10. Hasil Uji Organoleptik Mi Basah Pada Penelitian Utama

\begin{tabular}{|l|c|c|c|c|}
\hline \multirow{2}{*}{ Formula } & \multicolumn{4}{|c|}{ Nilai Rata-Rata Organoleptik } \\
\cline { 2 - 5 } & Rasa & Warna & Aroma & Tekstur \\
\hline Formulasi I & $4.11 \mathrm{a}$ & $4.32 \mathrm{a}$ & $3.97 \mathrm{a}$ & $3.94 \mathrm{a}$ \\
\hline Formulasi II & $3.87 \mathrm{a}$ & $4.04 \mathrm{a}$ & $3.90 \mathrm{a}$ & $4.06 \mathrm{a}$ \\
\hline Formulasi III & $3.93 \mathrm{a}$ & $4.21 \mathrm{a}$ & $3.81 \mathrm{a}$ & $4.31 \mathrm{~b}$ \\
\hline
\end{tabular}


1. Rasa

Tabel 10 memperlihatkan bahwa perlakuan formulasi I, II dan III menunjukkan hasil yang tidak berbeda nyata dalam segi penilaian organoleptik. Rasa yang tidak berbeda nyata dapat dipengaruhi oleh komposisi bahan yang digunakan, bahan baku yang digunakan antara formulasi I, II dan III yaitu tepung terigu, pasta ubi ungu, garam, natrium bikarbonat memiliki jumlah yang sama sedangkan jumlah penggunaan STPP dan CMC memiliki jumlah penambahan yang berbeda. Hal ini yang mengakibatkan rasa yang ditimbulkan tidak berbeda nyata. Selain itu uji organoleptik bersifat subjektif sehingga penilaian yang diberikan oleh panelis satu dan panelis lainnya tidak sama.

2. Warna

Data pada Tabel 10 memperlihatkan bahwa warna mi tidak berbeda nyata. Hal ini dapat disebabkan karena bahan baku yaitu pasta ubi ungu yang ditambahkan pada proses pembuatan mi basah jumlah pemakaian sama. Penambahan pasta ubi ungu menyebabkan wara ungu alami pada mi basah disebabkan oleh pigmen antosianin. Semakin meningkatnya penambahan pasta ubi ungu warna mi basah akan mempunyai kecenderungan semakin disukai oleh panelis.

3. Aroma

Data pada Tabel 10, dapat diketahui bahwa aroma mi tidak berbeda nyata antar perlakuan satu dengan perlakuan lainnya. Dikarenakan bahan yaitu pasta ubi ungu pada pembuatan mi ini yang digunakan memiliki jumlah yang sama dan aroma yang dihasilkan pada produk mi basah menghasilkan aroma khas ubi sehingga intensitas aroma yang diterima oleh masing masing penelis terhadap sampel satu dengan sampel lainnya tidak berbeda nyata.

4. Tekstur

Data Tabel 10 memperlihatkan formulasi I dan formulasi II tidak berbeda nyata antara perlakuan tetapi berbeda nyata dengan Formulasi III. Penambahan larutan garam alkali ke dalam mi ternyata dapat mempengaruhi mutu fisik mi. Mi yang menggunakan Sodium Trypolyphosphate (STPP) lebih elastis. Menurut Astawan (2006), Sodium Trypolyphosphate (STPP) dapat meningkatkan elastisitas dan ekstensibilitas adonan sedangkan $\mathrm{Na}_{2} \mathrm{CO}_{3}$ dapat meningkatkan kehalusan tekstur adonan. Sodium Trypolyphosphate (STPP) memiliki kemampuan untuk mengikat air yang terdapat dalam adonan sehingga air tidak mudah menguap dan tidak menyebabkan permukaan adonan menjadi kering dan keras sebelum proses pembentukan adonan.

Analisis Kimia Produk Mi Basah

Data pada Tabel 14, menunjukkan kadar protein hasil analisis mi basah yang dibuat dari ketiga formula memperlihatkan kadar protein lebih besar dari Standar Nasional Indonesia yang telah ditetapkan, yaitu sebesar $8 \%$.
Penurunan kadar protein pada mi basah dapat disebabkan oleh beberapa tahapan proses pembuatan mi basah yaitu pada saat proses pengulian adonan dapat menyebabkan kolapsnya struktur protein yang diakibatkan timbulnya panas selama pengadukan / pengulian. Pengadukan / pengulian menyebabkan energi kinetik dari molekul-molekul bahan dalam adonan menjadi besar, sehingga menyebabkan perubahan energi dalam dari bahan adonan.

Sodium Trypolyphosphate (STPP) dapat pula bereaksi dengan pati. Ikatan antara pati dengan fosfat diester atau ikatan silang antar gugus hidroksil $(\mathrm{OH})$, akan menyebabkan ikatan pati menjadi kuat, tahan terhadap pemanasan, dan asam sehingga dapat menurunkan derajat pembengkakan granula, dan meningkatkan stabilitas adonan. Sodium Trypolyphosphate (STPP) mampu menambah citarasa, memperbaiki tekstur (Shand, 1993).

Hasil analisis kadar air mi basah lebih besar dari pada syarat mutu mi basah menurut Standar Nasional Indonesia, yaitu maksimal sebesar 35\%, dapat dilihat Tabel 14. Kadar air mi basah yang dihasilkan hasil penelitian lebih tinggi dipengaruhi oleh STPP yang ditambahkan. Fungsi Sodium Trypolyphosphate di dalam pembuatan mi basah yaitu untuk membuka pori-pori bahan sehingga makin tinggi jumlah STPP menyebabkan bahan semakin porous. Hal ini menyebabkan air yang diserap oleh mi pada waktu pemasakan akan semakin banyak.

Daya serap air disebabkan ketika proses pemasakaan mi dimana terjadi proses gelatinisasi. Gelatinisasi adalah proses dimana air terperangkap di dalam granul pati yang menyebabkan pembengkakan granula pati dan tidak dapat berubah ke bentuk semula. Ketika proses gelatinisasi, terjadi perubahan sifat kimia, yaitu struktur kimia akan mengalami perombakan selama pemanasan, mengakibatkan bahan yang tadinya tidak larut menjadi larut.

Kadar Anthosianin Total Metode pH differensial Produk Terpilih

Antosianin adalah senyawa flavonoid dan berfungsi sebagai antioksidan. Zat warna alami antosianin dari bahan pasta ubi jalar ungu terbaik yang telah dicampurkan kedalam pembuatan mi kemudian dilakukan analisis kadar antosianin total dengan metode $\mathrm{pH}$ differensial, hasil analisis total anthosianin pada produk mi dapat dilihat pada Tabel 11.

Tabel 11. Hasil Analisis Total Antosianin pada Mi

\begin{tabular}{|c|c|}
\multicolumn{2}{|c}{ Basah } \\
\hline Bahan Baku & Total Antosianin \\
\hline Mi Masah & $16.90 \mathrm{mg} / \mathrm{l}$ \\
\hline
\end{tabular}

Data pada Tabel 11 menunjukkan kadar total antosianin pada mi basah yaitu sebesar 16.90 $\mathrm{mg} / \mathrm{l}$. Hasil yang didapatkan bila dibandingkan dengan hasil penentuan total antosianin pada pasta 
ubi ungu sebelum diaplikasikan pada mi basah memberikan hasil total antosianin yang berbeda, dimana setelah diaplikasikan kedalam mi basah total antosianin berkurang. Hal ini diakibatkan karena antosianin tidak stabil. Faktor-faktor yang mempengaruhi kestabilan antosianin antara lain pengaruh $\mathrm{pH}$, cahaya, dan suhu (Elbe \& Schwartz 1996).

Secara umum antosianin mempunyai kestabilan yang rendah. Selain mempengaruhi warna, pH juga mempengaruhi stabilitasnya. Antosianin lebih stabil dalam suasana asam daripada dalam suasana basa ataupun netral. Pada suasana asam antosianin berada dalam bentuk garam flavilium yang lebih stabil.

Dari Penelitian yang telah dilakukan, maka dapat diambil kesimpulan sebagai berikut :

1. Hasil penelitian pendahuluan menunjukkan penambahan volume air yang terpilih untuk dilakukan pada penelitian utama adalah penambahan air $500 \mathrm{ml}$ berdasarkan hasil uji organoleptik metode hedonik terhadap atribut warna, aroma, tekstur dan kenampakan.

2. Hasil analisis penelitian pendahuluan menunjukkan pasta ubi ungu memiliki kadar protein $1.1 \%$, kadar air $58.79 \%$. CMC kadar air $4.46 \%$, STPP $1 \%$, natrium bikarbonat $1.95 \%$

3. Hasil analisis penentuan total antosianin pada pada pasta ubi ungu sebesar $20.64 \mathrm{mg} / \mathrm{L}$

4. Hasil penelitian utama menunjukkan formula optimal terpilih dengan menggunakan program linier adalah formula III dengan harga terendah yaitu Rp. 1530,1280,- per 200 gram.

5. Hasil analisis kimia menunjukkan mi basah formula III memiliki kandungan protein sebesar $12.20 \%$ lebih besar dari syarat yang ditetapkan oleh SNI yaitu minimal 8\%. Dan kadar air mi basah hasil penelitian memiliki kandungan air sebesar $52.09 \%$ lebih besar dari syarat yang ditetapkan oleh SNI yaitu maksimal $35 \%$.

6. Hasil uji Hedonik pada penelitian utama memberikan nilai tidak berbeda nyata dalam hal rasa, aroma, warna pada ketiga formulasi tetapi berbeda nyata dalam hal tekstur.

7. Hasil analisis penentuan total antosianin pada Mi basah sebesar $16.90 \mathrm{mg} / \mathrm{L}$

\section{DAFTAR PUSTAKA}

1. Affy, S, (2010), Produksi Mi Kering Dari Ubi Jalar (Ipomea batatas) Varietas Unggulan, Skripsi, Fakultas Teknologi Pertanian Institit Pertanian Bogor.

2. Andre, P. (2004). Aplikasi Program Linear Dalam Penyususnan Formulasi Ransum Sapi Pedaging, Skripsi Fakultas Peternakan, IPB. http://seafast.ipb.ac.id//.

3. AOAC, (2005). Official Methods of Analysis of The association of Analytucal Chemist, washington, DC.
4. AOAC, (2006). Official Methods of Analysis of The association of Analytucal Chemist, washington, DC.

5. Arixs, (2006), Mengenalkan Olahan Bahan Pangan Nonberas Bali, Denpasar, www.cybertokoh.com, diakses 21 Juni 2012.

6. Astiti, W, (2012), Makan Mi Tiga Kali Seminggu,

http://rathikumara.blogspot.com/2012/02/maka n-mi-tiga-kaliseminggu.html, accesed, 24 Juni 2012.

7. Badrudin, C. (1994), Modifikasi Tepung Ubi Kayu (Manihot esculenta Crantz) sebagai Bahan Pembuat Mie Kering. Skripsi. Fakultas Teknologi Pertanian,IPB. Bogor.

8. Belitz, H.D and Grosh, W. (1999), Food Chemistry, Second Edition, Springer Verlag Berlin Heidelberg, Germany.

9. Elbe JH, Schwartz, SJ, (1996), Colorants, di dalam : Fennema OR, Editor. Food Chemistry. Ed ke-3. Marcel Dekker, New York.

10. Koswara, S, (2005), Teknologi Pengolahan Mi, eBookPangan.com

11. Kristianingsih, Rahayu, T, (2010), Petunjuk Pangan Gizi, Laboratorium Biologi Fakultas Keguruan dan Ilmu Pendidikan Universitas Muhammadiyah, Surakarta.

12. Oktaviani, (2005), Perubahan Karakteristik dan Kualitas Protein pada Mi Mentah yang Mengandung Formaldehide dan Boraks, Skripsi, Fakultas Teknologi Pertanian, IPB Bogor.

13. Potter W. and Norman, N. (1986), Food Science, The AVI Publishing Co, Inc. Westport, Connecticut.

14. Purnawiyanti, H, A, (2009), Mi Sehat, Penerbit Kanisius, Edisi Pertama Yogyakarta.

15. Rustandy, D, (2011), Produksi Mi, PT Tiga Serangkai Pustaka Mandiri,Edisi Pertama, Solo.

16. Shand, P.J., J.N. Sofos dan G.R. Schmidt, (1993) Properties of Algin/Calsium and Salt/Phosphate Strutured Beef Rolls with Added Gums. J. Food Sci. 58 (6).

17. Soim, A. (1998), Terigu Mahal Garut Tawarkan Diri, Edisi 343, Penerbit Trubus, Jakarta.

18. Standar Nasional Indonesia, (1992), Syarat Mutu Mi Basah, Badan Standarisasi Indonesia, Jakarta.

19. Steinbauer, L.E. dan L.J. Kushman, (1971), Sweet Potato Culture and Disease, Agriculture Hand Book No. 388, United State Departement of Agriculture. Washington D.C.

20. Suardi, D, (2005), Potensi Beras Merah untuk Peningkatan Mutu Pangan, Jurnal Litbang Pertanian 24 (3) Bogor.

21. Sugiono, Winarto, Achmad. S, (2008) Resep Produk Olahan Umbi-umbian dan Kacang- 
kacangan, Balai penelitian Tanaman Kacangkacangan dan umbi-umbianm.

22. Supranto, (1983), Linier Programming, Lembaga Penerbit Fakultas Ekonomi, Universitas Indonesia, Edisi Kedua, Jakarta.

23. Widyaningsih, (2006), Alternative Pengganti Formalin pada Produk Pangan. Trubus Agrisarana, Surabaya.

24. Winarti, Sarofa and Sri, Ulya And Anggrahini, (2008), Ekstraksi Dan Stabilitas Warna Ubi Jalar Ungu (Ipomea Batatas L.,) Sebagai Pewarna Alami, Jurusan Teknologi Pangan, Fakultas Teknologi Industri, UPN "Veterean" Jatim, Jurnal Teknik Kimia, Vol.3, No. 1. 